\title{
COOPERATION BETWEEN INSTITUTIONS OF THE EUROPEAN UNION AND ITS MEMBER STATES IN THE CREATION OF CLIMATE PROTECTION POLICY
}

\author{
Joanna Bukowska, Piotr Świat*
}

\begin{abstract}
The climate policy is a complex area of cooperation between Member States and the European Union institutions. The ambitious goals that the EU sets for itself in this matter are not always possible to be met by all Member States, hence the ability to work out compromise solutions is of great importance. Member States have various internal conditions, which determine the objectives of their economic and energy policies, therefore they do not always have convergent interests in this area.

The decision-making centre where the EU climate protection policy is created is: the European Council, where key elements of this policy are agreed (such as reduction targets), and the so called an 'institutional triangle', i.e. the EU Council, European Parliament and European Commission which are directly involved in the legislative process. This configuration is a platform where cooperation of the Member States manifests itself in various forms and intensity and where those countries may attempt to force their interests in the process of creating the EU policy.

The article presents the legal bases of the European Union's competences in the field of the climate policy and the role of the EU institutions in its creation with particular focus on mechanisms that allow Member States to influence the shape of that policy.
\end{abstract}

Joanna Bukowska - PhD in Law, Institute of Environmental Protection, National Research Institute; Piotr Świat - Institute of Environmental Protection, National Research Institute. 
Key words: Climate protection policy, conclusions of the European Council, conferred competences, the European emission allowance trading system (EU-ETS), institutional triangle, pre-emption effect, shared competences.

\section{INTRODUCTION}

The leader's position in tackling climate change, to which the European Union aspires, requires not only efficiency in negotiating ambitious international agreements but also a strong commitment to build foundations for their implementation at the internal European level with the necessity to consider fairly different levels of development and divergent interests of 28 Member States.

Those objectives have been framed in diverse timelines and action plans combining various targets and tools. A key element and, at the same time, a tool for achieving the objectives of the EU climate protection policy is the European emission allowance trading system in which the EU has developed the largest global market of allowances for emissions of carbon dioxide, a greenhouse gas of the highest significance. The consequences of the climate policy may also be seen in other areas of the EU policy, for instance in the promotion of the use of renewable energy sources by the Member States, the energy efficiency policy, the promotion of electromobility, etc. This has created a specific model of integration of diverse policies subordinated to the need to achieve the set greenhouse gas emission reduction targets ${ }^{1}$.

The current EU action plan in the field of promotion of the so-called low-emission economy provides that by 2050 the EU should reduce green-

1 The EU climate protection policy model corresponds with the general concept of environmental policy integration within which various policies are functionally interconnected. The main strand of this policy involves the commitment to reach a goal consisting in the limitation of greenhouse gas emissions in the economy, the limitation of the use of fossil fuels and the efficient consumption of energy and environmental resources. Moreover, the achievement of those objectives is supported by relevant investment projects and the financial policy of the EU Funds, which is integrated with them. For more on this issue see David Langlet and Said Mahmoudi, EU Environmental Law and Policy, Oxford University Press, 2016, 58-61. 
house gas emission levels by $80 \%$ as compared with 1990 . This objective is to be achieved by means of mid-term reduction targets of $40 \%$ by 2030 and of $60 \%$ by 2040 . The European Union programme also provides that the reduction targets will be achieved by the whole economy of its Member States and all its sectors ${ }^{2}$.

The climate protection policy objectives are developed by the EU at the international level within the framework of the Convention on Climate Change, the Kyoto Protocol (subsequently modified by the Doha Amendment), the Paris Agreement, as well as within the internal EU policy where the objectives related to combating climate change are one of the key elements of the EU's environmental policy as defined in Art. 191 Paragraph 1 of the TFEU. International commitments in the field of climate protection (i.e. the commitment to achieve emission reduction targets, to conduct systematic inventories of antropogenic emissions) undertaken by the EU and its Member States translate into the development of the EU and national policies aimed at the mitigation of and adaptation to climate change.

One of the EU's most advanced instruments designed in order to meet its global commitments on reduction greenhouse gas emissions is the Emissions Trading System (EU ETS) ${ }^{3}$ created in 2003 on the basis of Directive 2003/87/EC establishing a scheme for greenhouse gas emission allowance trading within the Community ${ }^{4}$. This has applied market solu-

2 Communication from the Commission to the European Parliament, the Council, the European Economic and Social Committee and the Committee of the Regions: A Roadmap for moving to a competitive low carbon economy in 2050, COM(2011) 112 final, also Jos Delbeke, Peter Vis, EU climate leadership in a rapidly changing world (in:) EU Climate Policy Explained, Jos Delbeke, Peter Vis, eds., European Union 2016: 21, see https://ec.europa.eu/clima/sites/clima/files/eu_climate_policy_explained_en.pdf .

3 Henri de Waele, 'Leyered Global Player. Legal Dynamics of EU External Relations', Springer, Berlin Heidelberg 2011: 91. However, it should be noted that the EU ETS is defined by the EU legislation and operates independently from the actions of other parties of the Climate Convention, underlining the EU commitment to tackle climate change. The EU ETS does not have an end date and continues beyond deadlines for the implementation of obligations under international agreements.

4 Directive 2003/87/EC establishing a scheme for greenhouse gas emission allowance trading within the Community, OJ [2003] L 275/32 (as amended). 
tions such as „cap and trade” scheme to induce entrepreneurs to reduce carbon dioxide emissions.

Even this brief description already indicates that the climate protection policy created at the EU level imposes significant constraints and financial effects on the Member States, especially on their economies and societies 5 .

The climate protection policy created by the EU is not an area of easy cooperation between the EU institutions and its Member States; quite on the contrary, in this regard, there are many areas where disputes arise. One of such areas entails the long- and medium-term objectives which the EU has declared in respect of greenhouse gas emission reductions. Another area involves the effect of the European Union policy on the energy security of the Member States and the right to decide on the use of energy resources, as well as the principles on the basis of which emission allowances are allocated as part of the above-mentioned EU emission allowance trading system. The Member States also oppose the so-called carbon leakage caused by the transfer of production in energy-intensive sectors to other countries where less restrictive emission reduction policy is in effect.

The broad compromise concerning in these matters among Member States is difficult to achieve and certain measures are adopted despite an objection from some of them, while the failure to consider the reservations voiced by them sometimes causes the Member States to take legal action against the EU legislator.

\section{THE EUROPEAN UNION'S COMPETENCE IN THE FIELD OF CLIMATE PROTECTION POLICY}

The EU's competence derives from the principle of conferred competences, which is laid down in Article 5 of the TEU. In accordance with this principle, the EU acts only within the limits of the competences conferred upon it by the Member States in the Treaties and exercises them to achieve

5 For more on this issue see Janina Ciechanowicz-McLean 'Prawne problemy umów międzynarodowych z zakresu ochrony klimatu' ['The Legal Problems of International Agreements on Climate Protection - in Polish] Gdańskie Studia Prawnicze 26 (2015): $115-116$. 
the objectives set out in them. All the competences which have not been conferred upon the European Union remain with the Member States. In turn, the manner of exercise of the EU's competences is governed by the principles of subsidiarity and proportionality, which limit the freedom of the EU legislator in the lawmaking process ${ }^{6}$. It is important to note that both the European Union and its Member States have shared competence to formulate the objectives and assumptions of the environmental policy as well as the climate protection policy, which is part of the former policy (the area of shared competences) ${ }^{7}$. Thus, in light of Article 2(2) TFEU, both the EU and the Member States may legislate and adopt legally binding acts in a given area. However, the Member States may exercise their competence only to the extent that the EU has not exercised its competence. Indeed, competences are not divided between the EU and the Member States in accordance to specific areas but they are delineated functionally, meaning that in regulatory terms the Union occupies those areas that are necessary to achieve the objectives laid down in the Treaties and indispensable for the implementation of the tasks of the European Union. Thus, the exercise of the shared competences by the Union means that the competences of the Member States are diminished, leading to their loss ${ }^{8}$ (the so-called pre-emption effect).

The Treaty has not laid down a sectoral division which would indicate which environmental issues fall within the EU competence and which are subject to the Member States' competence. There is no such division, either, in the sphere of the climate protection policy. Moreover, the EU climate policy does not derive from the climate policies created in the

6 Thus eg Sacha Garben and Inge Govaere, eds., The Division of Competences Between the EU and the Member States. Reflections on the Past, the Present and the Future, Hart Publishing, 2017, 6 and the literature cited there.

7 Art. 4 of the TFEU indicates that shared competences are neither exclusive competences laid down in Art. 3 of the Treaty nor the supporting, coordinating and complementary competences laid down in its Art. 6.

8 Przemysław Saganek, 'Komentarz do Art. 2 TFUE' ['A Commentary on Art 2 TFEU'] In: Traktat o funkcjonowaniu Unii Europejskiej. Komentarz [The Treaty on the Functioning of the European Union. A Commentary - in Polish] vol I arts 1-89 [online] Wolters Kluwer Polska, 2012 and the literature cited there <http://sip.lex.pl/\#/komen$\operatorname{tarz} / 587327076 / 124516>$. 
Member States. It is the policy created by the EU that shapes the internal policies of the Member States?. Although the Member States are involved in policy making through the participation of their representatives in decision-making bodies and centres, still the policy created by the EU does not derive from national policies. The Member States only adapt to the objectives of the EU policy which penetrates into the policies of the Member States and shapes them through its increasingly strict and direct application ${ }^{10}$.

It is at the EU level that the greenhouse gas reduction target is set for the Member States, the EU legislator also sets the greenhouse gas emission ceilings for the particular Member States with respect to the sectors which are not subject to the EU regulations on the emission allowance trading system (the so-called non-EU ETS sectors) ${ }^{11}$ and also sets the standards for the share of energy from renewable sources in the energy mix of those Member States.

However, the 'Europeanisation' in its fullest dimension manifests itself in the assumptions of the emission allowance trading system (the so-called EU ETS) which was established under Directive 2003/87/EC ${ }^{12}$. The EU regulations have come to dominate this area of the climate policy, with a large share of the EU Regulations, i.e. the regulations directly effective

9 Robert Ladrech, 'Party politics and EU climate policy' in S Minas and V Ntousas, eds., EU Climate Diplomacy. Politics, Law and Negotiations, Routledge, 2018, 14.

10 However, this feature is not specific to the climate policy only. Similar conclusions may be drawn for the environmental policy of the European Union. A substantial part of the Member States only adopt the minimum measures of environmental protection which the EU law requires from them, without going beyond these requirements (so-called gold-plating). See eg Ludwig Krämer, EU Environmental Law, Sweet\&Maxwell, 2016, 384-385.

11 These sectors include, inter alia, transport, agriculture and the municipal and housing sector. The national emission allocations were set for the greenhouse gas emissions from these sectors by the Commission Implementing Decision of 31 October 2013 on the adjustments to Member States' annual emission allocations for the period from 2013 to 2020 pursuant to Decision No 406/2009/EC of the European Parliament and of the Council [2013] OJ L292/21.

12 Directive 2003/87/EC of the European Parliament and of the Council of 13 October 2003 establishing a system for greenhouse gas emission allowance trading within the Community [2003] OJ L275/32 (as amended). 
and applicable in the national legal regimes. In addition, bearing in mind the fact that this system covers almost all the economic sectors of the Member States, including the energy sector, which in the case of certain countries is responsible for more than $70 \%$ of national carbon dioxide emissions, it must be concluded that the national policy on climate change mitigation in this area does not practically play any major role as it has been dominated by the EU policy.

It may also be noted that the EU climate policy is not always created by a consensus. Quite often its objectives reflect preferences of relatively powerfull European countries which influence the EU decisions taken at different levels ${ }^{13}$.

The main decision-making centre where the EU climate protection policy emerges is the so-called institutional triangle, consisting of the Council of the European Union, the European Parliament and the European Commission. In this field, the European Council plays a significant role, too. Together with the Council of the European Union, it forms an intergovernmental core of the EU. The operations of those institutions provide, at the same time, a platform on which the Member States cooperate in various forms and with varied intensity.

\section{Activity of the European Council in the Creation of the Climate Protection Policy}

The position of the European Council as an EU institution is laid down in Article 13(1) and 15 of the TEU. In accordance with Article 15(1) TEU, the European Council gives the Union the necessary impetus for its development and defines its general political directions and priorities. The very composition of the European Council somehow implies the need for the Member States to cooperate among themselves and reach consensus when taking decisions.

The Members of the Council are ex officio the Heads of State or Government of the Member States (Article 15(2) TEU)). Its composition also includes the President of the European Council and the President of the

13 Robert Ladrech, Party... 14. 
Commission, but - as persons who do not represent the Member States they do not part in voting ${ }^{14}$.

Those attributes make it possible for the European Council to determine key issues of strategic importance for the European integration and, as is often the case, problematic matters which have turned out to be politically too sensitive for the ministers making up a specific formation of the EU Council, e.g. fundamental decisions of the economic and monetary union, common foreign and security policy, as well as in matters in respect of which the EU Council has no horizontal coordination or when detailed issues going beyond the sectoral divisions need to be agreed ${ }^{15}$. Sometimes a decision of the European Council is needed to overcome an impasse in the decision-making process in the EU Council with regard to important issues related to the European integration ${ }^{16}$.

The so far-reaching competences of a political nature do not mean the corresponding legislative competences since the Treaty confers them upon the Council or the Council acting together with Parliament. Therefore, in principle, the European Council may not participate in the legislative process $^{17}$.

On the basis of those general competences laid down in Article 15(1) TEU, formally non-binding political decisions ${ }^{18}$ are taken which are called

14 The case is familiar for the High Representative of the Union for Foreign Affairs and Security Policy who takes part in the sessions of the European Council.

15 Kamil Ławniczak, Rada Unii Europejskiej. Organizacja i sposób działania [The Council of the European Union. Organisaton and the Mode of Operation - in Polish] University of Warsaw, 2014, 58; Neill Nugent, The Government and Politics of the European Union, Palgrave Macmillan, 2010, 163-165.

16 Anna Doliwa-Klepacka and Zbigniew M. Doliwa-Klepacki, Struktura organizacyjna (instytucjonalna) Unii Europejskiej [The Organisational (Institutional) Structure of the European Union - in Polish] Temida, 2009, 84.

17 In the area of the police and judiciary cooperation in criminal matters and in the area of social security, the European Council may exceptionally - at the request of the Member States - be involved in the process of negotiations on a given legal act.

18 It should not be confused with legally-binding decisions stated (e.g.) in Article 22 (1) and Article 26 (1) TEU.

${ }^{19}$ Although the provisions of the conclusions of the European Council are formally non-binding they oblige the institutions, in particular the EU Council, to act in accordance with them. Thus Jarosław Sozański, Prawo Unii Europejskiej [The Law of the Europe- 
'conclusions of the European Council'. In certain cases (e.g. in matters related to the European integration), those are 'guidelines'. Although the legal effect of those conclusions is not obvious ${ }^{19}$, this body has the right to adopt a position on practically all the issues related to the European integration and to take decisions in these matters, also in the form of legally binding political decisions to conclude international agreements of the EU. Pursuant to Article 22(1) TEU, the European Council is one of the main decision-making bodies as part of the common foreign and security policy and takes decisions in that matter, while pursuant to Article 21(2) (f) TEU, one of the objectives of this policy is to help develop international measures to preserve and improve the quality of the environment and the sustainable management of global natural resources, in order to ensure sustainable development.

Given the manner in which the European Council takes political decisions, those that are taken at its level must express a common position of all the Member States. It is all the easier for the European Council to reach such consensus as usually its decisions only concern matters of a general nature for which it is often much easier to reach a common position of the Member States than later when they work on detailed provisions of a draft legal act at the level of the EU Council.

The European Council is quite active in the scope of the environmental policy, especially in the field of air and climate protection. A review of its conclusions adopted in recent years indicates a number of significant decisions which the representatives of all the Member States managed to agree $^{19}$. In addition, it should be noted that apart from strategic decisions,

an Union - in Polish] Iuris, 2010, 87. Other authors indicate that as the European Council does not directly participate in the EU legislative process it has no competence to adopt independent and generally applicable legal norms. Thus, for instance, Aleksandra Szczerba-Zawada, 'Funkcje Rady Europejskiej w sferze unijnej władzy ustawodawczej' ['The Functions of the European Council in the Sphere of the EU Legislative Power' in Polish] Przegląd Sejmowy 114(2013): 49.

19 See European Council conclusions (2004 - to date) https://www.consilium.europa. eu/register/en/content/out/?typ=SET\&i=ADV\&RESULTSET $=1 \& D O C \_I D=\& D O S \_$ INTERINST $=\&$ DOC_TITLE $=\& C O N T E N T S=\& D O C \_S U B J E C T=C O N C L \&-$ DOC_DATE $=\&$ document_date_single_comparator $=\&$ document $\_$date_single_date $=\&-$ document_date_from_date=\&document_date_to_date=\&MEET_DATE=\&meet- 
e.g. those that laid down the 2030 climate and energy policy framework ${ }^{20}$, including the key decision in this respect - indicating the greenhouse gas emission reduction target for all the Member States, the European Council adopted a number of detailed arrangements to improve the emission allowance trading system, which has been recognised to be the main European instrument to achieve the reduction targets $s^{21}$.

However, essentially the political priorities in the sphere of the climate protection policy, which are set in the provisions of the conclusions of the European Council retain a general direction-setting nature. In its conclusions of 17 and 18 December 2015, the European Council invited the Commission and the Council to assess the results of COP 21, in particular in view of the 2030 climate and energy framework and to prepare the next steps. The Council also called on the Commission to swiftly submit legislative proposals to ensure the full implementation of the legislation on renewable energy and energy-efficiency and the preparation of an integrated strategy for research, innovation and competitiveness ${ }^{22}$.

In turn, in its conclusions of 22-23 June 2017, the European Council reaffirmed the commitment of the EU and its Member States to swiftly and fully implement the Paris Climate Agreement on climate, expressed its support for the idea of the EU leading in the fight against climate change and undertook to finance actions to protect the climate. It obliged the EU and its Member States to strengthen the cooperation with their inter-

ing_date_single_comparator $=\&$ meeting_date_single_date $=\&$ meeting_date_from date $=\&$ meeting_date_to_date $=\& D O C \_L A N C D=E N \& R O W S P P=25 \& N R$ ROWS $=500 \& O R D E R B Y=D O C \_D A T E+D E S C$.

20 The European Council laid down the 2030 climate and energy policy framework in its conclusions of 23-24 October 2014. See https://data.consilium.europa.eu/doc/document/ST-169-2014-INIT/en/pdf.

21 The European Council formulated guidance on the principles of the allocation of emission allowances to installations in the energy sector and announced that it would introduce the so-called market stability reserve. The Council presented its guidelines for the European Commission on the development of instruments and measures for technology neutral reduction of emissions from transport. It also announced that it would establish the policy on how to include land use, land use change and forestry into the 2030 greenhouse gas mitigation framework and also set a target of at least $27 \%$ for the share of renewable energy consumed in 2030 in the EU.

22 https://data.consilium.europa.eu/doc/document/ST-28-2015-INIT/en/pdf. 
national partners under the Paris Agreement, in particular with the most vulnerable countries, and also called on the Council and the Commission to examine all means to achieve those goals ${ }^{23}$.

In its conclusions of 22 March 2018, it invited the Commission to present by the first quarter of 2019 a proposal for a Strategy for longterm EU greenhouse gas emissions reduction in accordance with the Paris Agreement, taking into account the national plans ${ }^{24}$. In turn, in its conclusions of 13-14 December 2018, following the presentation of the Commission Communication 'A Clean Planet for All' and taking into account the outcome of the United Nations Framework Convention on Climate Change, 24th Conference of the Parties in Katowice, the European Council invited the Council to work on the elements outlined in the Communication and undertook to provide guidance on the overall direction and political priorities in the first half of 2019, to enable the Union to prepare a long term strategy by 2020 in line with the Paris Agreement ${ }^{25}$.

Even the guidelines of the European Council in the matters related to the European integration include a strand of the protection against climate change. The guidelines adopted in March 2018 on the conditions of the withdrawal of the United Kingdom of Great Britain and Northern Island indicated that the future partnership with the United Kingdom should address global challenges, in particular those in the areas of climate change, sustainable development and transboundary pollution in which the EU and the UK should continue their close cooperation.

The European Council continuously demonstrates its interest in the EU policy on climate protection. As indicated by the examples given above, the European Council is quite active in setting the policy directions and priorities in this field. Sometimes the European Council not only indicates the strategic goals in this field but also takes a position on certain detailed issues, e.g. the ways of improving the EU emission allowance trading system.

23 https://data.consilium.europa.eu/doc/document/ST-8-2017-INIT/en/pdf.

24 https://data.consilium.europa.eu/doc/document/ST-1-2018-INIT/en/pdf.

25 https://data.consilium.europa.eu/doc/document/ST-17-2018-INIT/en/pdf. 


\section{The Role of the Council of the European Union}

and Member States' Interests to Influence the Council's Decisions

in the Process of Creation of the Climate Protection Policy

The Council of the European Union holds a central position in the institutional system of the European Union. The Treaties have conferred upon it competences in the scope of legislation, budget, policy creation, control and international relations. It is a body which deals with all the EU policies, including its environmental policy, which for many years has included the policy on climate change mitigation.

The Council of the European Union is a platform for negotiations among the Member States and, at the same time, the main centre of power in inter-institutional arrangements. The Presidency of the Council plays a key role in working out a compromise solution ${ }^{26}$.

The Council of the European Union is a body where the interests of the particular Member States clash to the greatest extent. The members of the Council, designated by the national governments, represent, on the one hand, the interests of the respective Member States and, on the other, take decisions as the legislative body of the EU, seeking to serve a common interest.

The legislative function of the Council of the European Union is of key importance for its creation of climate protection policy.

Although the Council legislates in response to a proposal from the Commission, nevertheless the legislative proposals of the Commission are only the beginning of a long process of negotiations which are crowned by a vote on the adoption of a given legal measure. In many cases the Council has to assess the Commission proposals considering the economic situation of the Member States as well as their ability to achieve expected regulation objectives. It also assesses the adequacy, scope and effects of the

26 After the entry into force of the Lisbon Treaty the Presidency of the Council operates in a system of 18-month terms held rotationally by specified groups of three countries. This solution contributes to building a more consistent and more effective strategy of the European Union in a given field, to developing compromise solutions and to processing draft normative acts. 
solutions which are adopted. In this way, it verifies to a certain extent the priorities of the policy pursued or the manner of their implementation.

The Council of the European Union has the right to ask the Commission to carry out any analyses which it deems desirable for the achievement of common goals and to submit any relevant proposals. In this way, the Council can force the Commission to submit a proposal for the adoption of a legal measure in a matter on which, in its opinion, action needs to be taken.

The EU Council is not an autonomous body as the Ministers of whom it is composed follow the instructions adopted by the governments of the Member States and are accountable to them. They are also accountable to their national Parliaments ${ }^{27}$. Due to this dependence, the decisions taken by the representatives of the Member States in the EU Council are influenced by the current policy of the government of a given Member State and the political priorities it implements. Nevertheless, the overriding goal is to reach consensus and seek a compromise solution. This is the duty of both the States which support the adoption of a given measure and those that oppose it. Therefore, the Council decisions may be characterised as efforts to respect the national interests of the Member States, on the one hand, and, on the other hand, those seeking to serve a common interest.

The process of agreeing the contents of legal acts often reveals that the interests of the respective Member States do not always coincide and compromise solutions need to be worked out. It should be noted that although the need to reach consensus dominates the negotiations in the Council, following the principle nibil novi sine communi consensu, in the case of measures adopted to protect the climate, objections voiced by some Member States are not always taken into account. Sometimes the wish to swiftly adopt a measure outweighs the need to respect the interests of all the Member States as fully as possible. Such a situation took place in the

27 Cezary Mik, Europejskie prawo wspólnotowe. Zagadnienia teorii i praktyki [European Community Law. Issues of Theory and Practice - in Polish] C.H. Beck, 2000, 17. The EU Council, as the body composed of representatives of the Member States' governments, enables those governments to play an important role in shaping the EU position in most of the matters that the EU deals with. See Neill Nugent, Unia Europejska. Władza i polityka [original English title The Government and Politics of the European Union] Wydawnictwo UJ, Kraków 2012, 177. 
case of the vote on the Decision of the European Parliament and of the Council concerning the establishment and operation of a market stability reserve for the EU greenhouse gas emission trading scheme and amending Directive 2003/87/EC ${ }^{28}$, which was adopted in spite of objections of certain Member States.

In the matters of the EU climate policy, the Council essentially takes decisions by a qualified majority of votes as part of the so-called ordinary legislative procedure. The essence of this procedure is that decisions are taken jointly by the Council and the European Parliament after consultations with the Economic and Social Committee and the Committee of the Regions. This decision-making procedure is of basic importance in the adoption of measures in the field of the UE climate protection policy (Article 191, in conjunction with Article 192(1) TFEU). Although this procedure enables the adoption of a given act by the decision of a majority, it is quite generally held that in the legislative practice the States should seek to fully agree to adopt a given measure ${ }^{29}$.

It should also be noted that in the field of the environmental policy, the Treaty has laid down the above requirements for certain categories of legal measures adopted by the European Union (Article192(2)). Those requirements are reflected in the special legislative procedure which is reserved, inter alia, for the EU measures that would significantly affect the energy mix of a Member State and which requires a unanimous decision of the EU Council. In the special legislative procedure, the EU Council is the main legislator which adopts a legal act unanimously in response

28 Decision (EU) 2015/1814 of the European Parliament and of the Council of 6 October 2015 concerning the establishment and operation of a market stability reserve for the Union greenhouse gas emission trading scheme and amending Directive 2003/87/EC [2015] OJ L264/1. The main points of contention among the States were objections to amendments proposed by the Parliament with a view to introducing the reserve in question 2 years earlier and the doubts, which had not dispelled during the legislative process, as to the choice of the Treaty basis for the adoption of that Decision (some States claimed that the correct basis for this legal measure should be Art. 192(2)(c) TFEU, given the fact that the introduction of the market stability reserve may significantly affect the energy mix in certain Member States).

29 Thus Maria Kenig-Witkowska, ed., Adam Łazowski and Rudolf Ostrihansky, Prawo instytucjonalne Unii Europejskiej [The Institutional Law of the European Union in Polish] C. H. Beck, 2017, 115. 
to a proposal of the Commission after consultations with the European Parliament, the European Economic and Social Committee and the Committee of the Regions ${ }^{30}$.

It is important to note, too, that to date the legal acts which have created the EU climate protection policy have been adopted in the ordinary legislative procedure. The acts expected to contribute to a change in the energy mix of a Member State, e.g. the Directive on the promotion of energy from renewable energy sources, have also been proceeded in the ordinary legislative procedure rather than in the special legislative procedure ${ }^{31}$. Perhaps this situation may be explained by the tendency to enhance the role of the European Parliament in the process of creating the EU environmental policy, still it should be emphasised that this detracts from the powers of the Council and partly from the rights of the members of the Council, i.e. the representatives of the Member States.

In the special legislative procedure the role of a single Member State is growing, since an act of the Union may only be adopted by a unanimous

30 It seems that the assignment of the legislative function to the Council, combined with the requirement for unanimity, should be associated with the division of competences under the EU energy policy in accordance with which the Member States have the right to determine their energy mix (see Art. 194(2) second indent TFEU).

31 The Directive on renewable energy sources laid down binding targets on renewable energy for the respective Member States to be attained by 2020 (the target for Poland is $15 \%)$. It is deemed that with respect to the countries for which the highest targets have been set one can speak of a significant effect on the structure of energy supply and the choice between diverse energy sources (thus; Marcin Nowacki, Komentarz do art 194 Traktatu o funkcjonowaniu Unii Europejskiej, In: Traktat o funkcjonowaniu Unii Europejskiej Komentarz. Tom II ['Article 194' In: The Treaty on the Functioning of the European Union, vol II Art. 90-222 - in Polish], eds. Krystyna Kowalik-Bańczyk, Monika Szwarc-Kuczer, Andrzej Wróbel], Lex Omega, 2012. Cezary Mik, Wybór wtaściwej podstawy prawnej aktów wspólnotowego prawa wtórnego, ze szczególnym uwzględnieniem projektów aktów należących do pakietu klimatyczno-energetycznego [w:] Pakiet klimatyczno-energetyczny. Analityczna ocena propozycji Komisji Europejskiej [The choice of the appropriate legal basis for the secondary Community legislation, with particular emphasis on draft acts belonging to the climate and energy package In: Climate and energy package. Analytical evaluation of the European Commission proposals - in Polish]. Warszawa 2008, 18. Kim Talus, EU Energy Law and Policy: A Critical Account, Oxford University Press, 2013, ch 5.2; and, indirectly, Marjan Peeters, 'Governing Towards Renewable Energy in the EU: Competences, Instruments and Procedures’ Maastricht Journal 1 (2014): 43. 
decision of all the Council members ${ }^{32}$. Therefore in the field of the environmental policy, the choice of the legal basis essentially affects the Union's ability to make decisions and thus the implementation of the climate policy.

Given that the EU climate protection policy and regulations adopted in this field are often aimed directly at decarbonising Member States' economies and their energy mix towards low-carbon fuels ${ }^{33}$, the choice of the legal basis for the EU's act of law directly affects the interests of Member States ${ }^{34}$. There is also a natural need for States to push for legal solutions that will be less severe for their economies.

The main instruments for the exercise of the competences conferred upon the EU Council are various types of legal acts (regulations, directives and decisions $)^{35}$. The core of the EU climate protection policy consists of several legal acts adopted by decisions of the Parliament and the Council. They are as follows:

32 Konrad Łuczak, Norma art. 192(2)(c) TFUE jako podstawa prawna: skutki aktu prawnego i miks energetyczny państwa członkowskiego, [Article 192(2)(c) TFEU as a Legal Basis: Consequences of a Legal Statute and Energy Mix of a Member State - in Polish], Przegląd Legislacyjny 107.1/2019: 37.

33 For example, such assumptions formed the basis of Decision (EU) 2015/1814 of the European Parliament and of the Council on the establishment and operation of a market stability reserve for the EU greenhouse gas emission allowance trading scheme and amendment of Directive 2003/87 / EC, OJ. Office. EU L 264, 9/10/2015, p. 1, as demonstrated by travaux préparatoires developed by the Commission during the legislative process. See Commission Staff Working Document - Impact assessment accompanying the document Proposal for a Decision of the European Parliament and of the Council concerning the establishment and operation of a market stability reserve for the Union greenhouse gas emission trading scheme and amending Directive 2003/87/EC (SWD / 2014/017 final), pp. 14, 15, 49.

34 Unfortunately the jurisprudence of the EU courts is not very helpful in decoding the premises for using the special legislative procedure when designing acts in the field of environmental policy. One cannot resist the impression that the Court's guidelines are intended to authorise the current practice of the EU legislator rather than to seek a solution that will protect the rights of Member States in shaping the energy mix while exercising legislative powers in the field of the climate policy. See the conclusions on the ECJ judgment in case C-5/16 Poland vs. European Parliament and Council of The European Union, presented in the article of Konrad Łuczak, Norma art. 192(2)(c)....

35 Although the Council may express its position in the form of opinions, recommendations, conclusions or resolutions defining and coordinating policies, those measures are not applied in the area of the EU climate policy. 
a) Directive 2003/87/EC of the European Parliament and of the Council of 13 October 2003 establishing a scheme for greenhouse gas emission allowance trading within the Community;

b) Decision No 406/2009/EC of the European Parliament and of the Council of 23 April 2009 on the effort of Member States to reduce their greenhouse gas emissions to meet the Community's greenhouse gas emission reduction commitments up to $2020,{ }^{36}$ which will be replaced from 2021 by Regulation (EU) 2018/842 of the European Parliament and of the Council of 30 May 2018 on binding annual greenhouse gas emission reductions by Member States from 2021 to 2030 contributing to climate action to meet commitments under the Paris Agreement and amending Regulation (EU) No 525/2013 37 ;

c) Regulation (EU) No 525/2013 of the European Parliament and of the Council of 21 May 2013 on a mechanism for monitoring and reporting greenhouse gas emissions and for reporting other information at national and EU level relevant to climate change and repealing Decision No 280/2004/EC 38 ;

d) Regulation (EU) 2018/841 of the European Parliament and of the Council of 30 May 2018 on the inclusion of greenhouse gas emissions and removals from land use, land use change and forestry in the 2030 climate and energy framework, and amending Regulation (EU) No 525/2013 and Decision No 529/2013/EU ${ }^{39}$;

e) Regulation (EU) 2018/1999 of the European Parliament and of the Council of 11 December 2018 on the Governance of the Energy Union and Climate Action, amending Regulations (EC) No 663/2009 and (EC) No 715/2009 of the European Parliament and of the Council, Directives 94/22/EC, 98/70/EC, 2009/31/ EC, 2009/73/EC, 2010/31/EU, 2012/27/EU and 2013/30/EU

36 OJ [2009] L140/136 (as amended).

37 OJ [2018] L156/26 (as amended).

38 OJ [2018] L156/26 (as amended). Regulation (EU) No 525/2013 of the European Parliament and of the Council is to be repealed and replaced by the provisions of Regulation (EU) 2018/1999 of the European Parliament and of the Council of 11 December 2018 on the Governance of the Energy Union and Climate Action.

39 OJ [2018] L156/1. 
of the European Parliament and of the Council, Council Directives 2009/119/EC and (EU) 2015/652 and repealing Regulation (EU)

No 525/2013 of the European Parliament and of the Council ${ }^{40}$.

Those legal acts form the backbone of the EU climate protection policy and they are tools for fulfilling the EU commitments to reduce greenhouse gas emissions. Their list indicates that in the EU climate protection policy the law harmonisation principles diminish in importance in favour of methods for unifying regulation standards ${ }^{42}$. Moreover, this unification has a cross-cutting nature, covering all the key issues of the climate policy, starting by setting the limits for greenhouse gas emissions, through the principles of monitoring these emissions, their reporting and accounting for them, to sanctions imposed on units for failure to meet the obligation to account for emissions and measures to encourage the Member States to comply with the set emission limits.

The Council also plays an important role in the process of shaping the external relations of the EU by taking key decisions in the procedure of negotiations and signing international agreements of the EU. Article 191(4) TFUE provides the basis for concluding international agreements in the field of environmental protection. The agreements concluded by the European Union are binding for the EU institutions and the Member States. Pursuant to Article 218(2) TFEU, the Council authorises the Commission to open negotiations, adopts negotiating directives, authorises the signing of agreements and concludes them, acting in this respect, inter alia, together with the European Parliament. The Member States are particularly interested in laying down the negotiating directives for the Commission as those directives should reflect the real capacity of the Member States to meet the commitments which the EU makes in an international agreement.

\section{Initiative of European Commission}

In the institutional system of the EU the European Commission is an institution with a supranational profile ${ }^{41}$. In its activities, the Commis-

40 OJ [2018] L328/1.

${ }_{41}$ Neil Nugent, The European Commission (Macmillan 2001); David Spence, The European Commission (Longman 2006). The footnote after Maria Kenig-Witkowska (n 23) 119. 
sion has executive and control competences as well as those related to the lawmaking process, including the important power of exclusive and direct legislative initiative and the power to issue legal acts under the authorisation conferred in the legislative act.

The key power of the Commission in the sphere of creation of the integration policy entails the power of legislative initiative. In this way, the Commission externalises and operationalises the objectives of the EU policy in a given area. Although the legislative proposals of the Commission are then processed and amended in the course of the procedure by the entities which constitute the legislative body of the European Union (the EU Council and the European Parliament) the proposal for an act submitted by the Commission begins and gives shape to successive draft integration acts $^{42}$. As an institution, which supports the general interest of the European Union and, in addition, an institution independent of the Member States, the Commission has a relatively large margin of discretion in exercising its legislative initiative. Many regulatory initiatives of the Commission originate from the environmental action programmes which have been drafted since the early 1970s, however, they have not been the only and exhaustive programming basis for $\mathrm{it}^{43}$. Suggestions concerning new legislative initiatives of the Commission may also come from other sources. A large part of them is prepared in relation to a resolution issued by the Parliament or the Council in which the institutions may call on the Commission prepare and submit a proposal for a legal act. Similarly, in any matter the Member States may notify the need for a legislative proposal to be submitted or for existing legal acts to be amended.

A general principle of the climate protection policy is the adaptation of its objectives, assumptions and instruments to the changing conditions, including the commitments to reduce greenhouse gas emissions as well as to the experience gained in the scope of emission reduction methods and measures. As a result, a number of the EU legal acts in the field of climate

42 See eg Paul Craig and Grainne de Burca, EU Law. Text, Cases and Materials, Oxford University Press, 2008, 43.

43 Ludwig Krämer, EU Environmental Law..., 55. The Commission quite often submits regulatory initiatives which are not related to the environmental action programmes. 
policy include provisions obliging the Commission to perform a review of the mechanisms implementing the assumptions of this policy and to submit relevant conclusions to the Parliament and the Council.

The Commission oversees the application of the EU law and controls the Member States' compliance with the EU law and their obligations under the Treaties. As part of the control function, the Commission collects all the necessary information and verifies it. When it considers that a Member State fails to meet its Treaty obligations it may launch the infringement procedure under Article 258 TFEU. In the field of the climate protection policy, the infringement procedure has been seldom launched against the Member States for failure to comply with their obligations under the Treaty, although the Commission has undertaken controls many times. The reason for this is probably the special regulatory policy of the $\mathrm{EU}$ in this area which makes it easier for the Commission to exercise its control powers. This policy is characterised by a large share of unifying regulations (EU Regulations), with a small share of Directives which leave a certain margin of regulatory discretion to the Member States in the transposition process. This method of integration (a large share of unifying norms) enhances the ability of the Commission to control how the Member States execute the EU regulations. In addition, the regulations in the field of the climate policy give the Commission a large set of measure, by means of which it can continuously verify various types of information and data. Those measures ensure that for the control bodies the course of the integration processes in the Member States is almost fully transparent. Due to such a manner of exercising control and given the preventive instruments at the disposal of the Commission (the requirement for the consent of the Commission to a specific activity of a Member State), there is no justification for taking legal action against the Member States.

The Commission is a legislative body as many legal regulations entrust it with the acts of an implementing nature. The Commission exercises its legislative competences by issuing delegated and implementing acts.

In the discharge of its legislative functions, the Commission is supported by Committees which provide their opinions on the proposals for implementing acts before they are adopted by the Commission. The Committees, which are headed by an official from the Commission, con- 
sist of the representatives of all the Member States of the EU ${ }^{44}$. It is generally considered that the Committees enable the Member States to exercise control over the manner in which the Commission uses its executive powers ${ }^{45}$. However, a negative opinion of a Committee is not always binding for the Commission. Depending on the procedure, in case a negative opinion is provided the Commission is obliged either to take the position of the Committee into account when it issues a relevant implementing act, although it is not formally bound by the position, or decide not to adopt the act on which the Committee has provided a negative opinion.

A committee seldom provides a negative opinion on a proposal for an implementing act as in practice before a proposal is formally submitted for an opinion of the relevant committee the Commission consults the planned solutions with representatives of the Member States, thus verifying the rationale for a given proposal and the degree of its acceptability among the Member States. The Committees often establish working groups, consisting of its members who are interested in given proposals. Subsequently, they are formally submitted as proposals of the European Commission.

Essentially, the Member States have no influence on the exercise of delegated powers by the Commission. The European Commission has a very strong position in the political system of the EU. It is a body which is internally coherent and hierarchised; it has excellently organised information

44 After the reform implemented in 2011 the comitology committees have operated in accordance with three standardised procedures laid down in a Regulation of the European Parliament and of the Council: advisory and examination procedures, as well as a regulatory one combined with control.

45 Thus eg David Langlet and Said Mahmoudi, EU Environmental Law and Policy..., 24. Opinions provided by the Committee constrain to some extent the decision-making freedom of the Commission. Moreover, the choice of the procedure depends on the type and scope of implementing measures which the Commission is to adopt (the importance of the issues to be regulated by the Commission and the degree of freedom which the legislator is willing to confer on the Commission in its exercise of the implementing powers provided for in a primary act). Thus eg Cezary Herma, 'Komitologia - system wykonywania aktów prawnych we Wspólnocie Europejskiej' ['Comitology - System of Legal Act Execution in European Community' - in Polish] International Journal of Management and Economics 2 (2007): 16. 
resources, financial and human resource support, which ensure that it is best prepared in substantive and analytical terms compared with the other institutions involved in the legislative process. In the environmental policy and, in particular, in the climate protection policy, the Commission sometimes pushes measures which are inconsistent with the interests of the respective Member States. The more the States cannot agree in a given case the easier it is for the Commission to develop its own policy, autonomise and escape the control of the Member States ${ }^{46}$. In order to implement the policy solutions which it recommends, the Commission often seeks support from certain Member States which represent preferences close to those proposed by the Commission, at the expense of the achievement of a broad compromise among all the Member States.

The Member States have limited capabilities of affecting the manner of implementation of the competences entrusted to the European Commission. Essentially, their activity only consists in their participation in the procedures whereby the Commission exercises its legislative competences. However, such powers are gradually diminished as at present the legislative powers of the Commission much more frequently take the form of delegated rather than implementing acts. Such a tendency may also be seen in the field of the EU climate protection policy.

\section{Influence of the European Parliament on the Creation of the Climate Protection Policy}

The participation of the European Parliament in the creation of the EU internal policy entails its implementation of the legislative function, where, in addition to the Council, it acts as a lawmaking body in the ordinary legislative procedure, the consultative function, as well as the exercise of political control (Article 14(1) first sentence TEU).

It is also important to note the appointment function of the Parliament related to the election of the President of the Commission (Ar-

46 Janusz Ruszkowski, Ponadnarodowość w systemie politycznym Unii Europejskiej [Supranationality in the Political System of the European Union - in Polish] Wolters Kluwer, 2010, 212. 
ticle 14(1) second sentence TEU) and the approval of its members ${ }^{47}$. Bearing in mind the role of the President of the Commission, including his influence on the choice of policy priorities, inter alia, their environment-friendly approach, by exercising its appointment function the Parliament may to some extent determine the direction of the EU policy in a given field. In turn, the participation in the procedure to appoint the President of the European Commission (the election of the candidate for its President) is itself an example of cooperation between institutions one with a supranational profile and the other being an emanation of the will of the Member States. At the interface between the appointment and control functions, there is the power of the Parliament to carry a motion of censure of the Commission, which results in the resignation of its members as a body (Article 17(8) TEU (and Article 234 TFEU)). This power ensues from the responsibility of the Commission as a body to the European Parliament and applies to the Commission as a whole rather than its respective members. The Treaties do not provide for the control powers of the Parliament with respect to the Council, although the members of the Council are accountable to the national Parliaments in their Member States (article 10(2) TEU).

The control function of the Parliament entails primarily its right to submit questions to the Council or Commission. This right is exercised by a committee, a political group or a group of at least 40 Members of the Parliament (Rule 128 of the Rules of Procedure of the European Parliament). Control is also exercised by the right to accept petitions in the matters falling within the scope of activity of the EU.

As part of its consultative function, a number of opinion-providing powers has been conferred upon the European Parliament, both of a specific nature - especially where it does not participate in the legislative procedure (see in particular Article 192(2) TFEU cited below) - and a general

47 In this respect, Art. 17(7) TEU is particularly important. In accordance with it, the European Council, acting by a qualified majority, proposes to the European Parliament a candidate for President of the Commission. The candidate is elected by the Parliament by a majority of its members. Subsequently, the European Commission as a whole (its President, its other members and the High Representative of the Union for Foreign Affairs and Security Policy) are approved by the European Parliament by a vote of consent. This procedure has been specified in Rule 118 of the Rules of Procedure of the European Parliament. 
one (Rule 133 of the Rules of Procedure of the European Parliament provides that any Member of the Parliament may table a motion for a resolution on a matter falling within the scope of activity of the EU).

The legislative function of the European Parliament is of key importance for the creation of the environmental policy and the climate policy as its part. Its legislative function is limited to some extent by the fact that it has no power of legislative initiative ${ }^{48}$ and that it has no influence on the choice of the procedure to adopt a legislative act. This is important as although, in principle, legal acts on the environment under Article 192(1) TFUE are adopted in the ordinary legislative procedure - the special legislative procedure is applied to the matters referred to in Article 192(2)(a)(c) TFUE. In this procedure, the participation of the European Parliament is limited to consultations.

The competent committee of the European Parliament in environmental matters is the Committee on the Environment, Public Health and Food Safety. However, in many cases those matters may also fall within the scope of activity of the Committee on Industry, Research and Energy with powers in particular in the scope of the EU measures related to the energy policy in general and the establishment and functioning of the internal energy market.

Taking into account the supranational profile of the European Parliament, the members of which represent the European nations rather than the Member States, the latter have limited influence on the activity of the European Parliament.

\section{Participation of the National Parliaments in the Process of Creation of Secondary Law}

The Lisbon Treaty enabled the Parliaments of the Member States to participate in the legislative process and in the implementation of certain EU policies.

48 Pursuant to Art. 225 TFEU, the European Parliament may only request the European Commission on a non-binding basis to submit a proposal for an act of law which it deems to be necessary to implement the Treaties. 
Pursuant to Article 12 TEU, the national Parliaments contribute actively to the efficient functioning of the European Union. For this purpose special powers have been conferred upon them, including the right to be informed by the institutions of the EU, to receive draft legal acts of the EU as well as the competence to ensure that the principle of subsidiarity (and to a lesser extent the principle of proportionality) are respected.

In order to implement those powers, two protocols have been annexed to the Founding Treaties. The purpose of the Protocol on the Role of National Parliaments in the European Union is to enable the Parliaments to take a position on the matters which are the subject matter of legislative work in the $\mathrm{EU}^{49}$. To this end, the EU institutions are obliged to forward to the national Parliaments consultation documents (inter alia, green and white papers), annual legislative work programmes, any other instruments of legislative planning or policy and any draft legislative acts.

The other document is the Protocol on the Application of the Principles of Subsidiarity and Proportionality ${ }^{50}$. Pursuant to its Article 6, any national Parliament may by a certain date send to the Presidents of the European Parliament, the Council and the Commission a reasoned opinion stating why it considers that the draft in question does not comply with the principle of subsidiarity. In turn, Article 7(1) provides that the insti-

49 Moreover, Art. 10 of the Protocol provides that a special conference of Parliamentary Committees for Union Affairs may submit any comments it deems appropriate for consideration by the European Parliament, the Council and the Commission. Such a conference may also organise interparliamentary conferences on specific topics, in particular to address matters of the common foreign and security policy, including the common security and defence policy.

50 Each institution ensures constant respect for the principles of subsidiarity and proportionality, as laid down in Art. 5 of the Treaty on European Union. Art. 5 of the Protocol on the Application of the Principles of Subsidiarity and Proportionality provides that draft legislative acts are to be justified with regard to the principles of subsidiarity and proportionality. In turn, each of them should contain a detailed statement making it possible to appraise compliance with the principles of subsidiarity and proportionality (so as to enable at least an assessment of the financial impact of a given proposal for an act and, in the case of a directive, of its implications for the regulations to be laid down by the Member States). The argument that a EU objective can be better achieved at the EU level must be substantiated by qualitative and, wherever possible, quantitative indicators. 
tutions of the EU which have initiated the legislative process should take into account the reasoned opinions adopted by the national Parliaments.

\section{CONCLUSIONS}

Bearing in mind that cooperation in developing the climate policy is so challenging in political terms given the economic and social implications of the implementation of its assumptions, the achievements of the EU in this area should be appreciated. This policy is characterised by a very high level of ambition in the scope of greenhouse gas emission reductions, which is outstanding in itself, in light of the large differentiation of its Member States in terms of their energy structure and the technological advancement of various industrial sectors.

There is no doubt that the cooperation between the European Union and the Member States in creation of the climate protection policy is supported by the institutional arrangements presented here, which have originated from the division of competences laid down in the Treaties and the Treaty rules on the exercise of the competences entrusted to the Union.

However, it should also be added that the ability of the Member States to influence the directions and range of the EU policy on climate change mitigation is also determined by factors other than legal ones, such as the capacity to convincingly present policy preferences, the ability to form alliances with other States with coincident interests or the continuity of the national policy in a given field.

\section{REFERENCES}

Ciechanowicz-McLean, Janina, 2016, 'Prawne problemy umów międzynarodowych z zakresu ochrony klimatu' ['The Legal Problems of International Agreements on Climate Protection -in Polish] Gdańskie Studia Prawnicze 26. Delbeke Jos, Vis Peter, 2016, EU climate leadership in a rapidly changing world (in:) EU Climate Policy Explained, Jos Delbeke, Peter Vis, eds., European Union 2016, https://ec.europa.eu/clima/sites/clima/files/eu_climate_policy_explained_en.pdf. 
Doliwa-Klepacka, Anna and Zbigniew M. Doliwa-Klepacki, 2009, Struktura organizacyjna (instytucjonalna) Unii Europejskiej [The Organisational (Institutional) Structure of the European Union - in Polish] Temida.

Garben, Sacha and Inge Govaere, eds., 2017, The Division of Competences Between the EU and the Member States. Reflections on the Past, the Present and the Future, Hart Publishing.

Herma, Cezary, 2007, 'Komitologia - system wykonywania aktów prawnych we Wspólnocie Europejskiej' ['Comitology - System of Legal Act Execution in European Community' - in Polish] International Journal of Management and Economics 2.

Iwańska, Barbara, 2017, 'Ochrona powietrza w systemie ochrony środowiska' ['Air Protection in the Environmental Protection System' - in Polish] Europejski Przegląd Sądowy 7.

Kenig-Witkowska, Maria, ed., Adam Łazowski and Rudolf Ostrihansky, 2017, Prawo instytucjonalne Unii Europejskiej [The Institutional Law of the European Union - in Polish] C. H. Beck.

Krämer, Ludwig, 2016, EU Environmental Law, Sweet\&Maxwell.

Ladrech, Robert, 2018, 'Party politics and EU climate policy' in S Minas and V Ntousas, eds., EU Climate Diplomacy. Politics, Law and Negotiations, Routledge.

Langlet David and Said Mahmoudi, 2016, EU Environmental Law and Policy, Oxford University Press.

Ławniczak, Kamil, 2014, Rada Unii Europejskiej. Organizacja i sposób działania [The Council of the European Union. Organisaton and the Mode of Operation - in Polish] University of Warsaw.

Łuczak, Konrad, 2019, Norma art. 192(2)(c) TFUE jako podstawa prawna: skutki aktu prawnego i miks energetyczny państwa członkowskiego, [Norm of art. 192 (2) (c) TFEU as a legal basis: the effects of a legal act and the energy mix of a Member State - in Polish], Przegląd Legislacyjny.

Mik, Cezary, 2000, Europejskie prawo wspólnotowe. Zagadnienia teorii i praktyki [European Community Law. Issues of Theory and Practice - in Polish] C.H. Beck.

Mik, Cezary, 2008, Wybór właściwej podstawy prawnej aktów wspólnotowego prawa wtórnego, ze szczególnym uwzględnieniem projektów aktów należących do pakietu klimatyczno-energetycznego [w:] Pakiet klimatyczno-energetyczny. Analityczna ocena propozycji Komisji Europejskiej [The choice of the appropriate legal basis for secondary Community legislation, with particular emphasis on draft acts belonging to the climate and energy package In: 
Climate and energy package. Analytical evaluation of the European Commission proposals - in Polish], Warszawa.

Nowacki, Marcin, 2012, Komentarz do art 194 Traktatu o funkcjonowaniu Unii Europejskiej, In: Traktat o funkcjonowaniu Unii Europejskiej Komentarz. Tom II ['Article 194' In: The Treaty on the Functioning of the European Union, vol II Art. 90-222 - in Polish], eds. Krystyna Kowalik-Bańczyk, Monika Szwarc-Kuczer, Andrzej Wróbel], Lex Omega.

Nugent, Neill, 2001, The European Commission, Macmillan.

Nugent, Neill, 2010, The Government and Politics of the European Union, Palgrave Macmillan.

Nugent Neill, 2012, Unia Europejska. Władza i polityka [original English title: The Government and Politics of the European Union] Wydawnictwo UJ, Kraków.

Peeters, Marjan, 2014, 'Governing Towards Renewable Energy in the EU: Competences, Instruments and Procedures' Maastricht Journal 1.

Ruszkowski, Janusz, 2010, Ponadnarodowość w systemie politycznym Unii Europejskiej [Supranationality in the Political System of the European Union - in Polish] Wolters Kluwer.

Saganek, Przemysław, 2012, 'Komentarz do Art. 2 TFUE' ['A Commentary on Art 2 TFEU'] In: Traktat o funkcjonowaniu Unii Europejskiej. Komentarz [The Treaty on the Functioning of the European Union. A Commentary in Polish] vol I arts 1-89 [online] Wolters Kluwer Polska.

Sozański, Jarosław, 2010, Prawo Unii Europejskiej [The Law of the European Union - in Polish] Iuris.

Szczerba-Zawada, Aleksandra, 2013, 'Funkcje Rady Europejskiej w sferze unijnej władzy ustawodawczej' ['The Functions of the European Council in the Sphere of the EU Legislative Power' - in Polish] Przegląd Sejmowy (1) 114.

Talus, Kim, 2013, EU Energy Law and Policy: A Critical Account, Oxford University Press de Waele, Henri, 2011, Leyered Global Player. Legal Dynamics of EU External Relations, Springer, Berlin Heidelberg.

The article was written as part of the Project 'Knowledge base on climate change and adaptation to its effects and channels of its dissemination in the context of increasing the resilience of the economy, environment and society to climate change, and counteracting and minimising the effects of extraordinary threats', co-financed from the Operational Programme Infrastructure and Environment 2014-2020. 